\title{
Striving for a restitution of the former splendor? Reasons for municipal splits in Poland
}

\begin{abstract}
Shaping the administrative division of the country is influenced by various factors. Based on the analysis of 22 municipal divorces in Poland between 1995 and 2019 the article attempts to identify the determinant factors of these splits. The article examines environmental (economic or cultural) and political factors which may stimulate the fragmentation initiatives. The results indicate that in Poland cultural factors appear to be at least as important as economic ones. An argument of great significance in the process of a new municipality creation (both in the case of successful and unsuccessful splits) was the memory of the inhabitants about the time when they were operating as a separate municipality. In case of rural municipalities the existence of a second almost equally important population centre in the municipality was an important factor contributing to the municipal splits.
\end{abstract}

Keywords

Territorial reforms $\bullet$ local government $\bullet$ fragmentation $\bullet$ territorial division • Poland

(c) University of Warsaw - Faculty of Geography and Regional Studies

Introduction

Studies on the fragmentation of municipalities are usually present in literature either in the context of territorial reforms or in studies and debates around the optimal size of a local government unit. The latter research in its empirical dimension has focused on analysing changes in territorial division (for example, Baldersheim \& Rose 2010; Wollmann 2010; see the literature review in Swianiewicz et al. 2016 also). Research on consolidation reforms (merging municipalities) clearly dominates - this is the dominant direction of local government reforms in most of the countries described in literature, at least in relation to Western Europe.

Shaping the administrative division of a country is influenced by various factors - political and economic (e.g. related to globalization processes) and spatial and demographic (e.g. the development of large cities and metropolitan areas). A review of recent studies shows that economic arguments prevail among those justifying territorial reforms. Most often they are related to the costs of service delivery/economies of scale and argue rather for the amalgamation of territorial units (Gendźwiłt, Kurniewicz \& Swianiewicz 2020). Taking into account the municipal (lowest) tier only and the first two decades of the twenty-first century, we can identify many European countries that have experienced territorial reforms in the form of amalgamations (e.g. Macedonia, Georgia, Denmark, Latvia, Albania, Ireland, Estonia). As a result, the total number of municipalities in Europe has decreased by over 10,000 between 1990 and 2014' (Swianiewicz et al. 2017). However, over that period, reforms also occurred in the opposite

\footnotetext{
${ }^{1}$ The total number of municipalities in 40 European countries in 1990 was close to 116,000 . In the first half of the 1990 s, the number of local governments increased (reaching 120,000 in 1994), mainly due to the tendency towards fragmentation in Eastern Europe. In subsequent years, territorial consolidation tendencies began to prevail which led to a decrease in the number of municipalities to 106,000 in 2014 (Swianiewicz et al. 2017)
}

\author{
Julita Kukomska $\mathbb{C}$ \\ Chair of Development and Local Policy, \\ Faculty of Geography and Regional Studies, \\ University of Warsaw, Poland \\ e-mail: j.lukomska@uw.edu.pl \\ Received: 19 May 2020 \\ Accepted: 10 December 2020
}

direction in some European countries, and this manifested in territorial fragmentation. In the early 1990s such reforms took place in Croatia, Czech Republic, Slovenia and Hungary. At that time, several dozen municipalities were also divided in Poland and Slovakia. The rationale for the changes in these countries was to regain a high degree of municipal autonomy at the cost of territorial fragmentation, whereas previous regimes had sought centralization (Swianiewicz et al. 2017). Empowered communities were increasingly aware of the importance of locality and defended the right to self-rule. Units that had earlier been deprived of local government representation began to demand corrections to territorial division, taking into account their right to self-governance (Kaczmarek 2016). Since the mid-1990s, cases involving municipal splits have been quite common in several countries in this part of the continent, including in Poland.

The administrative division of Poland has been the subject of much analysis and evaluation in the literature (Chojnicki \& Czyż 2000; Miszczuk 2003; Izdebski 2009; Swianiewicz 2014; Kaczmarek 2016; Swianiewicz et al. 2016; Swianiewicz 2018).

The diagnosis made by institutions of Central Government in relation to territorial division is changing. In 2001, the Polish parliament recognized the new basic territorial division of the country as correct and meeting the assumptions of public administration reform. But in 2013 the Ministry of Digitization and Administration, in their report on the situation of local governments, claimed that: 'A number of local governments are small and financially weak. In time, they may not be able to handle the more difficult and expensive public tasks of an ageing country' (Ocena sytuacji ... 2013). But the conclusion in this report was based on very simplistic data, and a singledimensional analysis of the impact of size. Similar conclusions can be found in the report prepared for the same Ministry in 2014 
by Swianiewicz. He claims that large units are able to perform some tasks more cost-effectively and have a higher ability to perform some tasks that cause difficulties for the smallest local governments. In relation to the proposed changes to the map of municipalities in Poland, the author emphasizes that each case must be considered individually, and that large territorial areas and specific geographical conditions can sometimes be a strong argument for maintaining the separateness of a small administrative unit (Swianiewicz 2014).

The thesis about the relationship between the size of a unit and the costs of performing public services in Polish local governments has been confirmed by the results of more detailed research (Swianiewicz et al. 2016). To a large extent, the results of the analysis indicate the significance of the size factor of the local government unit. But the authors do not explicitly support territorial consolidation, arguing that saying that small municipalities cope with some tasks worse than large ones does not necessarily mean that merging them into larger units would improve the situation (Swianiewicz et al. 2016). In another study these same authors analyse the effects of municipal splits that have taken place in Poland in the last 20 years, including using a quasi-experimental research scheme. They admit that the division of a municipality leads to better financial results and they confirm an economy-of-scale effect in relation to administrative spending but not in relation to the operating surplus of the budget. The authors also note that internal conflicts between parts of a municipality may sometimes have a highly paralyzing effect on the quality of local policies, and a 'divorce' could be the best solution, releasing the positive activity of the local community and improving the quality of governance (Swianiewicz \& Łukomska 2019).

But in the studies mentioned above, not much was said about the reasons for the fragmentation in cases in Poland. The arguments that underpin the municipal splits in Poland are largely understudied. Two studies that come close to the topic only discuss the reasons for the splits indirectly (Kaczmarek 2016; Swianiewicz, Gendźwiłł \& Łukomska 2018).

In the period from 1995 to 2019 , there were 22 secessions of municipal parts from mother municipalities in total in Poland. The aim of this article is to answer the research questions: why do secession initiatives appear in particular municipalities but not in others? and can a common pattern across those municipalities be identified?

The Polish cases of territorial fragmentation analysed in this article can be classified as a Girondin type of Baldersheim and Rose typology (2010). These splits were not a part of a comprehensive reform implemented at the Central Government level. They took place as a result of a grassroots initiative of groups seeking to establish separate local government units (they were accepted by national government ${ }^{2}$ but came from local individual authorities). We can treat them as an example of incremental changes that involved only a few municipalities at a time (they did not lead to major change - at most, to the minor adjustment of the existing territorial division). At the same time, a strong local voice in the decision-making was present in almost all Polish splits.

Regarding the stage of collecting information on the cases of municipal divisions in Poland between 1995 and 2019, I mainly used the desk research method. The data provided by the Polish Main Statistical Office ${ }^{3}$ the Ministry of Finance ${ }^{4}$

${ }^{2}$ In the Polish legal procedure, competences in the field of territorial changes to local government units were granted exclusively to the Central Government which could create a new local government unit on its own initiative (usually the Ministry of Interio and Administration was directly involved) or at the request of the municipal council.

${ }^{3}$ Mainly data from the Statistic Poland Local Data Bank (2020) available on the website: https://bdl.stat.gov.pl/BDL/start

${ }^{4}$ Budget execution data of local governments received from the Ministry of Finance.
Table 1. Number of municipalities in Poland (1991-2018)

\begin{tabular}{|c|c|}
\hline Year & Number of municipal governments \\
\hline 1991 & 2420 \\
\hline 1994 & 2468 \\
\hline 2000 & 2489 \\
\hline 2002 & 2478 \\
\hline 2010 & 2479 \\
\hline 2014 & 2479 \\
\hline 2018 & 2478 \\
\hline
\end{tabular}

Source: Main Statistical Office

and the Ministry of Interior and Administration ${ }^{5}$ turned out to be particularly useful.

The article is divided into four parts. Part one presents context and the main statistics related to the municipal divorces that took place in Poland in the last 15 years. Part two discusses the reasons for these divisions, distinguishing their types: economic, cultural and political. In the third part, cases of unsuccessful municipal splits are catalogued and briefly described. Part four concludes the article.

\section{Municipal splits - the Polish context}

The total number of municipalities in Poland seems to have remained stable over the last 25 years (see Table 1).

The current territorial division of municipalities was introduced in 1973 as a result of merging smaller units of local government that usually consisted of several villages. In the place of 4,313 smaller municipalities (called gromada at that time ${ }^{6}$ ), 2,367 larger local governments were created (Kiełczewska-Zaleska 1974). In the second half of the 1970s, the process of territorial consolidation continued and, as a result, there were 2,348 municipalities in 1978 (including the districts of the five largest cities). The subsequent years brought a very slow reversal of this trend; in 1988 the number of local governments had increased to 2,399 .

The restitution of local government, free elections for local authorities, the revival of local patriotism, and the initial lack of a state vision for the transformation of territorial administration at county and regional level were the main conditions for the significant territorial reorganization of local structures towards territorial fragmentation in the early 1990s. As a result of the democratization of public life after 1990, the number of municipalities increased.

A significant part of the fragmentation process was related to the division of urban-rural municipalities ${ }^{7}$ into two separate units: urban and rural. In 1991 such a change was accepted in as many as 23 cases (ed. Jałowiecki 1995). Such changes usually took place as a result of grassroots pressure and conflicts between

${ }^{5}$ Draft legal acts concerning the creation of new municipalities: Ministry of the Interior and Administration and Regulations of the Council of Ministers

${ }^{6}$ These were units of the vertical state administration structure which operated in 1954-1972.

${ }^{7}$ In Poland urban municipalities only cover a given city within its administrative boundaries; rural municipalities usually consist of rural areas (excluding metropolitan areas). A separate type of municipality distinguished in Poland is the urban-rural municipality. Typically, it consists of a small town and surrounding rural areas. In the early 1990 s, some of these municipalities split into two parts. Usually both jurisdictions retained the same name of the municipality, so two neighbouring local governments of the same name were created as a result: the central urban municipality and the surrounding rural municipality. 


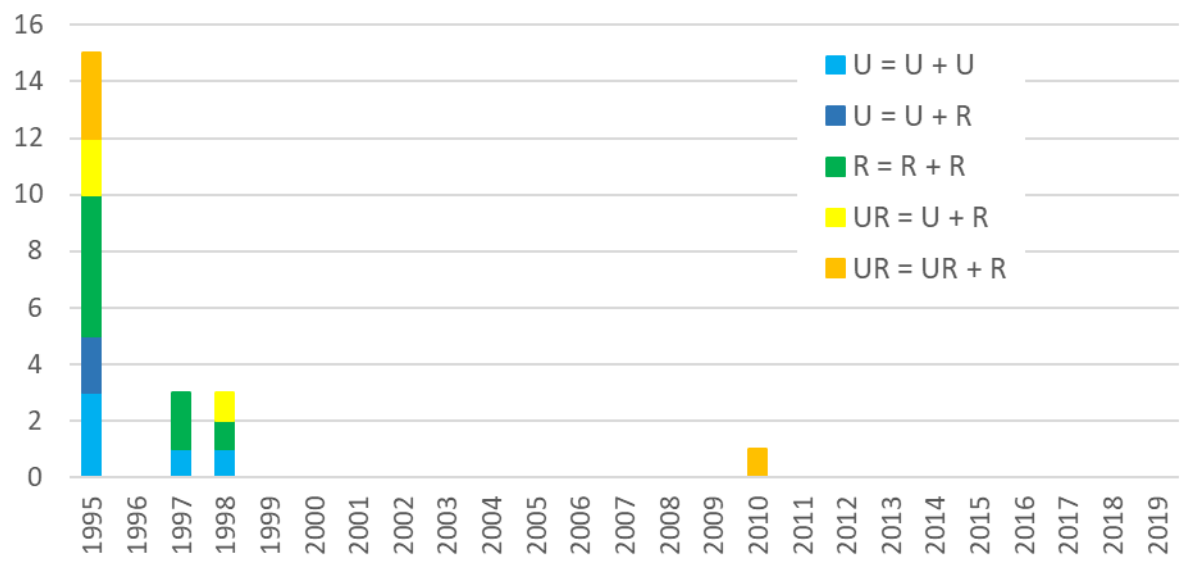

Figure 1. Timing and type of municipal divorces in Poland (1995-2019)

Note: $U$ - urban municipality, $R$ - rural municipality, UR - urban-rural municipality; e.g. $U=U+U$ means the division of an urban municipality into two urban local government units

Source: own calculation based on Main Statistical Office (2020) and Ministry of Interior and Administration data (2020).

communities (especially the local elites) in the rural and urban parts of the municipality. In the early 1990s, the administrative division of large cities into districts that were separate municipalities was also abolished; the districts only survived in Warsaw, until 2002 (Swianiewicz 2014). After the liquidation of Warsaw's municipalitydistricts in 2002, the number of municipalities in Poland remained very stable. This was connected, among other things, with the change in the Central Government's policy on the fragmentation of municipalities. The establishment of new municipalities was limited after 1998 when the second level of local government - the county - was restored. At that time, Central Government introduced more stringent criteria for creating municipalities, taking into account demographic, infrastructural and economic factors. ${ }^{8}$ The provisions of the Act on Local Government, referring to maximum homogeneity/territorial cohesion and the ability to perform public tasks, were interpreted more rigorously, resulting in applications for reactivating municipalities being increasingly met with a negative assessment by the Ministry (Kaczmarek 2016). This is why, in Figure 1, we can observe such a long break in municipal divisions. The exception to this rule was the creation of Jaśliska ${ }^{9}$ (rural municipality), which in 2010 (after several previous refusals by the Ministry) separated from the urban-rural municipality of Dukla (see Fig. 1).

The subject of analysis in this article is the municipal splits since 1995 only, due to a problem accessing generally available data on previous years. In 1995 alone, 15 new municipalities were created. These were different types of changes: 5 urban, 5 rural and 5 urban-rural municipalities were divided at that time. The newly created local government units (secessionists) were primarily rural municipalities (12 out of the 15 cases of splits in 1995). Later municipal divisions were much rarer (Fig. 1). The analysed municipal divorces were not a result of a conscious policy of the Central Government (they were not part of a central policy programme), but rather occurred as a result of bottom-up pressure and singular initiatives from local political elites and local communities (Gendźwiłł, Kurniewicz \& Swianiewicz 2020).

${ }^{8} \mathrm{~A}$ detailed description of the formal procedure for creating municipalities in Poland and the explanation of the criteria introduced in 1998 can be found later in the article ('Political factors' section).

${ }^{9}$ The local community of Jaśliska made huge efforts to reactivate local government. See the 'Political factors' section, where the individual characteristics of Jaśliska, which contributed to the positive decision of the Central Government regarding the division of the local government, is described.
On the basis of the collected data, we may say that the newly created municipalities strongly vary in terms of their population size (see Fig. 2). The smallest 'secessionist' had less than 2,000 inhabitants, while the largest was inhabited by almost 10 times more people (over 18,500). Only 3 of the secessionists had over 10,000 inhabitants at the moment of division. Looking at the size of the new local governments in the context of the model of territorial organization in the country, we note that almost $70 \%$ of the newly created municipalities (initiators of the splits) are smaller than the average Polish municipality at that time (measured by the median population size). Maybe the size of the municipalities before the division was too big, which is why they decided to split. The collected data show that, in $60 \%$ of the analysed cases, the municipalities before the split were bigger than the national mean population size.

Analysing the relative size of the 'initiator of the split' and the 'abandoned unit' we notice that the initiator is usually a smaller part of the former municipality. In 20 out of 22 cases 'initiators' were smaller than 'abandoned' municipalities (Fig. 3). The desire to break away from a 'big brother' was often related to a sense of marginalization of interests on the part of the much smaller unit $^{10}$ (Swianiewicz, Gendźwilł \& Łukomska 2018). In such cases, the political representation of the potential secessionist in the local government council was too small to effectively defend its interests. The biggest difference in size between the initiators and the abandoned municipalities concerned small towns and suburban areas in Upper Silesia that were incorporated into the borders of large mining cities during the consolidation reform in the 1970s. Amalgamated municipalities were not like classic suburban areas - 'dormitory towns' of large cities - but were autonomous socio-economic and spatial units with their own workplaces and developed service centres. That is why, immediately after 1989, when local government was again a possibility, the administrative aspirations of these areas, dormant for years, woke up (Jarczewski 2002).

Reasons for municipal secession initiatives in Poland overview

It is important to answer the question of why the analysed municipalities split. Most of them decided to become separate

${ }^{10} \mathrm{~A}$ more detailed discussion of this type of motive for the division of municipalities can be found in the next section ('Economic factors'). 


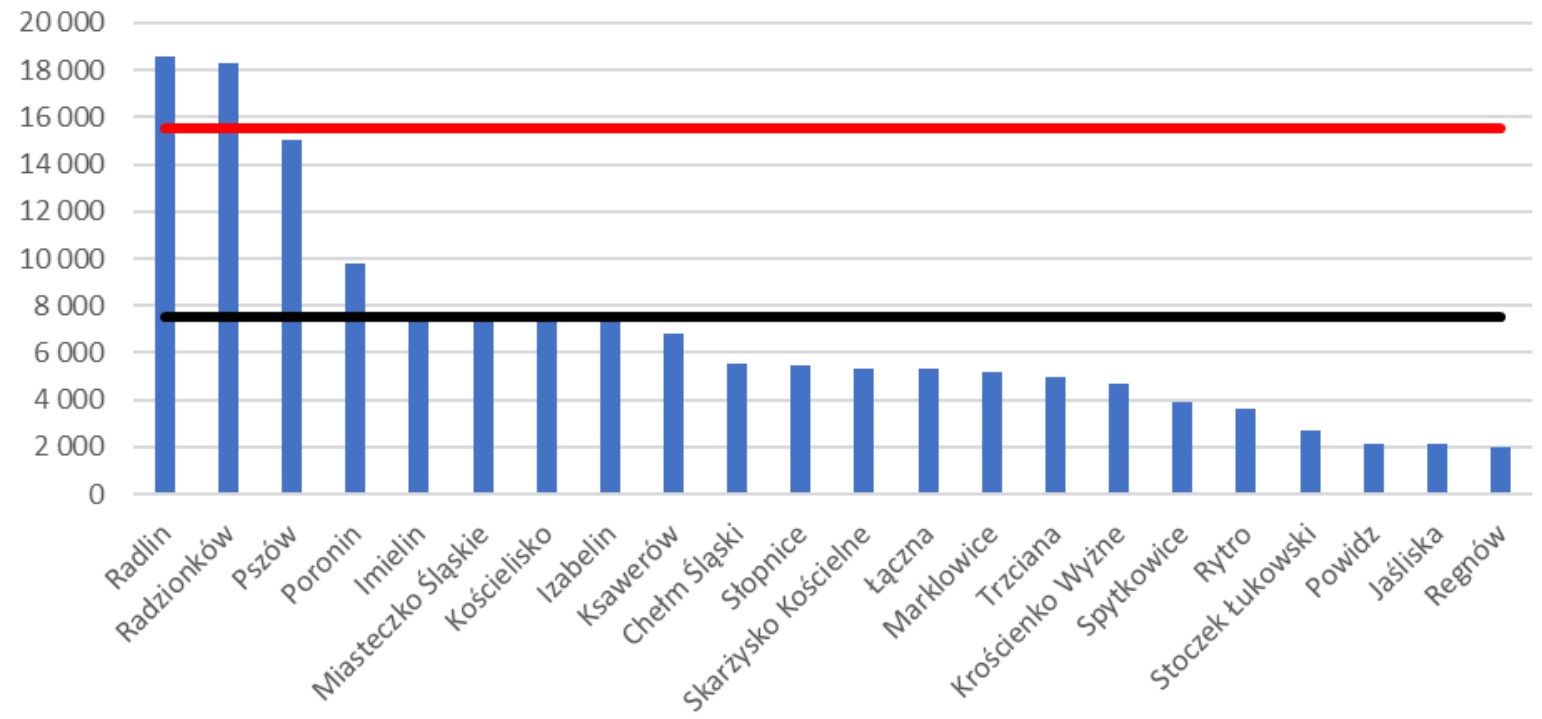

Figure 2. Population size of new municipalities in Poland (data from the year of municipal splits; mean and median from 1995) Source: own calculation based on Main Statistical Office (2020) and Ministry of Interior and Administration data (2020).

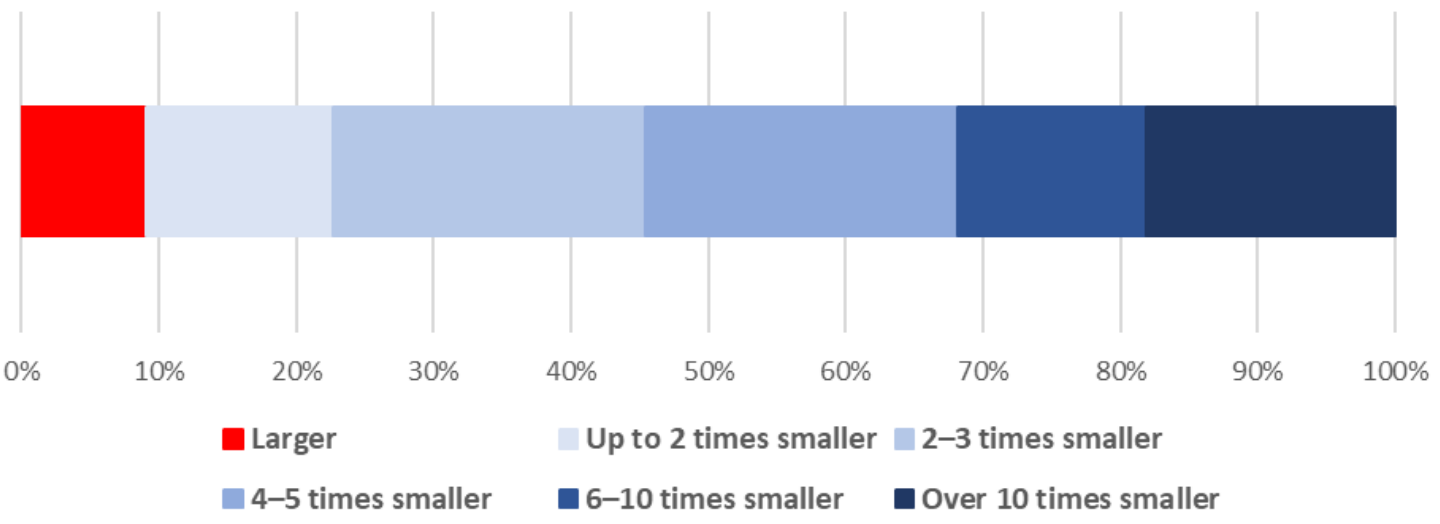

Figure 3. Ratio of population size of the 22 new (initiator) to abandoned municipalities Source: own calculation based on Main Statistical Office (2020) and Ministry of Interior and Administration data (2020).

units in the mid-1990s. Their decisions to split were certainly associated with many specific circumstances that were characteristic of that time in Poland. In that context, the following elements should be noted:

$\checkmark \quad$ territorial division, inherited from the socialist period, was not fully accepted. It corresponded to the reality of a centrally planned system (no counties until 1998, small regions);

$\checkmark \quad$ the lack of statutory provisions regarding specific criteria for the division of municipalities (which were only introduced in 1998) ${ }^{11}$ contributed to the fact that Central Government's control of this process was not very restrictive or demanding for municipalities that wanted to divide;

$\checkmark \quad$ the democratization of public life after the political upheaval of 1989-1990 enabled grassroots social movements to develop, including those aimed at the regaining of autonomous local governments; the development of the third sector of economy;

$\checkmark \quad$ less than 20 years had passed since many units disappeared

${ }^{11}$ See the 'Political factors' section for a detailed presentation of the fragmentation process rules in Poland, the changes in those rules, and specific criteria introduced in 1998. from the administrative map of the country as a result of the previous consolidation reforms;

$\checkmark$ the process of lively democratization of public life had an impact on the emergence of political differences, e.g. among municipal councillors on ideas for local development (Kaczmarek 2016).

We need to analyse the reasons for municipal secession initiatives in a more systematic way. Referring to the model proposed by Swianiewicz (2021) we will look carefully at environmental and political factors that may have stimulated the fragmentation initiatives.

Inspired by Erlingsson's study (2005) Swianiewicz divided environmental factors into economic and cultural ones.

Reasons for municipal secession initiatives in Poland economic factors

In the literature, we can look for arguments for decentralization and justifications for the optimal size of municipalities to identify the factors explaining the attempts at secession of local governments. The theoretical economic 


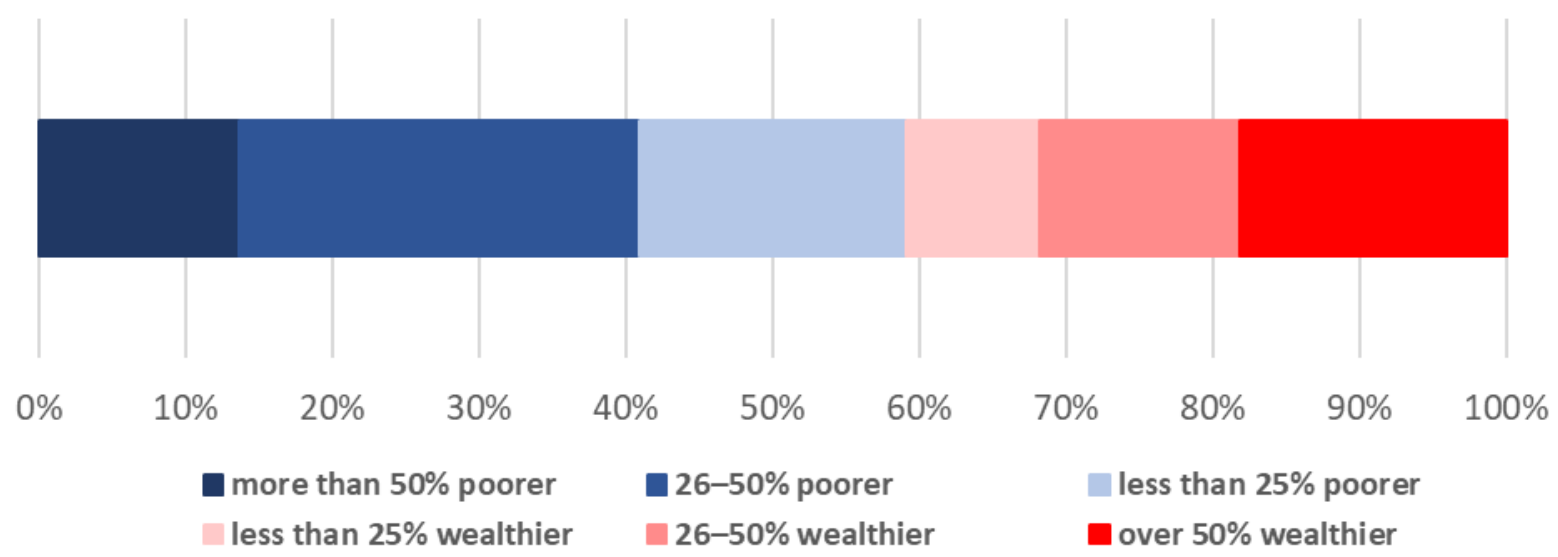

Figure 4. Ratio of the affluence of local budget of the 22 new (initiator) to abandoned municipalities Source: own calculation based on Ministry of Finance (2020) and Ministry of Interior and Administration data (2020).

arguments for fragmentation focus on claims that smaller units of local governments: deliver services more efficiently and are more responsive to constituent needs (Hogen-Esch 2001); have more homogeneous preferences (Alesina \& Spolaore 2003); enable a welltailored 'tax-service package' to be delivered (i.e. local tax rates optimally balanced with the level of public services that fit local preferences) (Gendźwilł, Kurniewicz \& Swianiewicz 2020). Moreover, gains from large-scale economies are not valid for all services and public goods (Ladd 1994; Fox \& Gurley 2006) and merging local units has the potential to reduce competition between local governments and to generate rent-seeker monopolies - with high taxes and low efficiency (Nelson 1992).

Erlingsson (2005) indicates the following two economic factors among the plausible reasons behind a particular units' wish to secede: secession of the rich (more affluent parts of municipalities are more inclined to support secession initiatives) and the feeling of being used/exploited/unfairly treated (the feeling of being marginalized by the other part of the municipality due to not enough investments or insufficient access to local services, for example).

In 9 out of the 22 Polish cases of municipality splits after 1995, the secession led to the separation of a richer part of the local government from a poorer part (Fig. 4). The affluence of the local budget was measured by own revenues per capita in the year of the division. In 7 of those cases the difference in affluence was over $25 \%$ of the local tax base.

The biggest difference in affluence could be seen in the case of Stoczek Łukowski, where the urban part of the municipality (being the initiator of the division) was almost three times wealthier than the rural part. It was the political elites of the urban part of the municipality that sought the division. City councillors were less numerous and felt exploited by the group elected in the many surrounding villages that formed the 'pro-rural coalition' in the local council. As a result, there was a growing belief among inhabitants of the town that most of the development funds were allocated to the rural part and the town was being increasingly neglected. The mayor of the municipality (who opposed the division) ordered an expert assessment to be prepared by the Communal Development Agency, which was supposed to show the negative economic effects of the divorce. When the initiators of the division succeeded in 1998 (supported by influential central level politicians), the mayor gave up his candidacy for the next term. In Stoczek Łukowski there were no clear geographical barriers that could affect the sense of separateness. What is more, the town of Stoczek Łukowski is a natural centre for the inhabitants of the surrounding villages (Swianiewicz, Gendźwiłł \& Łukomska 2018). Geographical location was not an important factor that might have influenced the split of the municipality. Other environmental factors were much more important in this case, related both to economic factors (as mentioned above and indicated by Erlingsson (2005) combined with: 'secession of the rich who felt exploited and marginalized') and to the historical experience of operating separately (until 1992, when rural and urban parts were consolidated into one administrative unit) (Swianiewicz, Gendźwiłł \& Łukomska 2018).

Among other units with a big difference in affluence of local budgets between initiators and abandoned municipalities, we mainly find towns and suburban areas in the densely populated and highly urbanized mining region of Upper Silesia (Marklowice, Miasteczko Śląskie, Chełm Śląski). As mentioned in the previous part of the article these units were not classic suburbs. An important argument for their restitution was their significant economic independence. Large companies operated in their area, generating revenues for the municipal budget. Arguments related to the feeling of being marginalized were also present in social initiatives, mainly conducted by local leaders. The most frequently used arguments were related to the underdevelopment of the municipality during the years of their lack of independence, poor political representation in the local authorities of the municipality, and poor infrastructural and functional links with the city centre (Kaczmarek 2005).

However, it should be noted that the majority of the cases under analysis did not concern the 'secession of the rich' argument, since the initiators of the splits were less wealthy than the abandoned parts of the municipalities.

Reasons for municipal secession initiatives in Poland cultural factors

Among cultural and identity factors of municipal fragmentation, as described by Erlingsson (2005) and Swianiewicz (2021), we can distinguish at least 3 types $^{12}$ of situation in which:

$\checkmark$ there are two or more municipal centres of similar importance in the municipality,

$\checkmark$ distance to the town hall is too long and/or access to local services is limited,

$\checkmark$ inhabitants had not forgotten about the time when they operated as a separate municipality.

${ }^{12}$ These aspects of the cultural push for secession are related to the argument of the proximity between citizens and their representatives. Erlingsson (2005) characterizes them using the expression: 'the borders were inappropriately drawn'. 
There are examples in the literature of studies that suggest that split initiatives are often a delayed reaction to amalgamation reform (Brink 2004; Tabguay \& Wihry 2008; Illner 2010; Drew \& Dollery 2014). The splits of the municipalities being researched in this article can also be interpreted as a quite-distant-in-time (about 20 years) reaction to the compulsory, non-democratic merger reforms imposed by the communist regimes. It was possible only after the political upheaval in 1990 that the 'suppressed' local communities began the struggle to regain their own autonomous local governments. The 'drive for secession' could have been strengthened by the fact that the initiator of the split had been an economically or culturally important centre in the past and many inhabitants used to refer to the 'historical days of glory' when they were at the stage of 'the battle' for the restitution of local government (as mentioned in the first part of the article, the case of the Polish municipality Jaśliska, which used to be an important centre of trade on a major route from Hungary in late medieval times and in the following centuries). In a situation where there was a tradition of separation in the past, sometimes the initiators of the division referred to the merger of municipalities, and sometimes even to a feeling of harm. In some cases, the separating municipalities had historical traditions of being urban centres (e.g. Miasteczko Śląskie, which was an urban centre until 1945 and between 1962 and 1975; Jaśliska, until 1934; Imielin, between 1967 and 1975; Pszów and Radlin, between 1954 and 1975).

All analysed cases of municipalities created after 1995 had an element of functioning as separate municipal governments in their history (Table 2). Of these cases, the municipality of Stoczek Łukowski experienced it for the longest period (from 1973, there were two independent municipalities - rural and urban - which functioned as separate units until 1992). All Silesian municipalities (except for Chełm Śląski) and almost all municipalities located in the mountains (Jaśliska, Kościelisko, Poronin, Spytkowice) also had their short independent history of operation as a bigger municipality (after the consolidation of smaller municipalities in 1973). All in all, in 13 of the cases under research the larger municipalities were reactivated but only for almost 3 years (they survived until the administrative reform of 1975 when they were incorporated into other units). Therefore, these were mainly municipalities in which the conditions of either economic independence or geographical location argued for the existence of a separate administrative unit. Most incorporations in the 1970s met with social dissatisfaction in the liquidated units (Jarczewski 2002). The incorporated municipalities were usually localized far away from city centres or centres of consolidated areas; they were separated from them by green belts, wasteland, industrial areas or geographical forms of terrain, for example mountain ridges or passes. As a result, infrastructure and communication links between the combined units were often poor.

What is interesting in the context of the fragmentation of municipalities may be the concentration of population in the area of the municipalities. A situation in which there were two municipal centres of similar importance in the municipality (a town in which the seat of the municipality was located, and another almost equally important population centre) may have contributed to the split of the local government. In such a situation we could expect that the inhabitants of the second centre might want to demand independence. To verify the hypothesis in terms of Polish divorces, we can compare the population size of the village that became the seat of the new municipality after the secession (initiator) with the number of inhabitants in the population centre that was the seat of the municipality before the division. Due to data unavailability, we can only analyse this in rural and urban-rural municipalities ${ }^{13}$ for 2009 , which is a methodological problem. ${ }^{14}$ The assumed hypothesis is more likely in those cases in which the ratio of the population centre of the initiator to the abandoned local government is close to 1 , or greater than 1 . So, this condition (indicating the strong population centre of the initiator) was not met in 7 of the cases of splits (mainly divorces in the urban-rural municipalities). But in most cases (8, mainly splits of rural local governments) the initiator was very similar (or even bigger) to the abandoned unit in terms of the size of the population centre (Table 3).

A good illustration of cultural fragmentation factors is the example of the split in Raba Wyżna. In this case, the initiators of the divorce were the inhabitants of Spytkowice, which in the not-too-distant past had been an independent unit, and later joined Raba Wyżna. An important reason for the divorce was precisely the sense of separateness associated with the memory of its independent past. Geographical conditions also played a significant role - the village of Spytkowice was relatively poorly connected to the rest of the municipality. Spytkowice is located along an important national road and is in the neighbouring valley, which is separated from Raba Wyżna by a low mountain ridge. Road connections between Spytkowice and the seat of the municipality of Raba Wyżna are less convenient than, for example, those from Spytkowice to the nearby town of Rabka Zdrój. This factor, like that of its history, creates a clear sense of separateness, which translates into a sense of the need for its own local government. Additionally, in the case of Spytkowice and Raba Wyżna, the initiator of the division was more prosperous - the difference in potential (measured by income from own revenues per capita) was about 50\% (Swianiewicz, Gendźwiłł \& Łukomska 2018).

Reasons for municipal secession initiatives in Poland political factors

The political factors leading to fragmentation can be analysed on two levels: central and local. Due to the lack of data on the 'party colour' of local councillors by place of residence in the early 1990s, the political factors at the central level will be addressed in this article. They are mainly related to legal regulations concerning splits. Swianiewicz (2021) distinguished three dimensions:

$\checkmark \quad$ legal framework favourable for splits (power of decisions on splits, regulation on consultations),

$\checkmark$ policy of Central Government (attitude towards splits),

$\checkmark \quad$ influential political patron of the split.

In Poland, the Central Government is responsible for the shape of territorial division. The change in the number of municipal governments does not require any voting by the parliament.

Competence regarding territorial changes of local government units was given exclusively to the Central Government, which may create a new local government unit on its own initiative or at the request of the municipal council. In this case, Central Government must take into account the following requirements:

- maximum homogeneity/territorial cohesion of the municipality through the analysis of the spatial system and social, economic and cultural ties;

the ability to perform public tasks by the municipality.

${ }^{13}$ Out of the 22 analysed cases, 7 concerned the divisions of urban municipalities, another 7 were related to the fragmentation of urban-rural municipalities and the remaining 8 were splits of rural municipalities (this is also shown in Figure 1).

${ }^{14}$ It would be more appropriate to use data from before the division of the local government. In cases where data is unavailable, it must be assumed that the 2009 data are the best possible approximation of the 1995 data. 
Table 2. Historical past of newly created municipalities after 1995 regarding their functioning as separate administrative units

\begin{tabular}{|c|c|c|c|c|}
\hline & $\begin{array}{l}\text { Separate municipality } \\
\text { in } 1954-1972\end{array}$ & $\begin{array}{l}\text { Amalgamated } \\
\text { in } 1973\end{array}$ & $\begin{array}{c}\text { Amalgamated in } 1975 \text { (separate } \\
\text { municipality in 1973-1975) }\end{array}$ & $\begin{array}{c}\text { Amalgamated after } \\
1975 \text { (when?) }\end{array}$ \\
\hline Izabelin & + & + & & \\
\hline Jaśliska & + & & + & \\
\hline Kościelisko & + & & + & \\
\hline Krościenko Wyżne & + & + & & \\
\hline Ksawerów & + & & + & \\
\hline Łączna & + & + & & \\
\hline Poronin & + & & + & \\
\hline Powidz & + & & + & \\
\hline Regnów & + & + & & \\
\hline Rytro & + & + & & \\
\hline Skarżysko Kościelne & + & & + & \\
\hline Słopnice & + & + & & \\
\hline Spytkowice & + & & + & \\
\hline Stoczek Łukowski & + & & & 1992 \\
\hline Trzciana & + & + & & \\
\hline Chełm Śląski & + & + & & \\
\hline Imielin & + & & + & \\
\hline Marklowice & + & & + & \\
\hline Miasteczko Śląskie & + & & + & \\
\hline Pszów & + & & + & \\
\hline Radlin & + & & + & \\
\hline Radzionków & + & & + & \\
\hline
\end{tabular}

Source: own desk research

It is usually the Ministry of Interior and Administration that decides territorial changes through regulation, after consulting with several other organizations, such as the interested municipal council (and county or regional councils in the case of changes in the boundaries of counties and regions). The opinion of the relevant council should be preceded by consultation with the residents (which may take the form of a local referendum, but this is not obligatory).

The institution of the local referendum for the creation of the new municipality was introduced by the provisions of the amendment of the Act on Local Government of May 2011.15 A local referendum may be held to establish a municipality on the initiative of the residents (a group of at least 15 people). The referendum should include citizens of the whole local government affected, not just the part that wishes to secede. The referendum should not be conducted if the analysis carried out before the referendum shows that as a result of the division of the municipality:

${ }^{15}$ Journal of Laws 2011 , No. 134 , item 777 . Prior to this, referendums could also be organized, but only on the basis of general referendum rules.
1. revenues from the local tax base per capita of the new municipality would be lower than the lowest in the country at that time (the Ministry of Finance indicates the value),

2. the new local government would be smaller than the smallest currently existing in Poland (in terms of the number of inhabitants). The relevant governor is responsible for the analysis in this regard.

A local referendum is valid if the turnout exceeds the minimum threshold of $30 \%$.

The positive result of such a referendum is binding for the municipal council in the sense that the council is obliged to apply to the Central Government to issue a regulation. However, the final decision on the creation of the new municipality remains within the exclusive competence of the Central Government.

The attitude of the Polish Central Government towards municipal splits has changed over time. In the early 1990s, there were no restrictions on the creation of new municipalities. After passing the formal procedure (usually preceded by the results of the referendum and social petitions to the regional and 
MISCELLANEA GEOGRAPHICA - REGIONAL STUDIES ON DEVELOPMENT

Vol. $25 \cdot$ No. 1 • 2021 • pp. 71-81 • ISSN: 2084-6118 • DOI: 10.2478/mgrsd-2020-0047

Table 3. Comparison between the number of inhabitants of the population centres in initiator and abandoned municipalities (data from $\left.2009^{16}\right)$

\begin{tabular}{|c|c|c|c|c|}
\hline & $\begin{array}{l}\text { Number of inhabitants } \\
\text { of the population } \\
\text { centre (initiator } \\
\text { municipality) }\end{array}$ & & $\begin{array}{l}\text { Number of inhabitants } \\
\text { of the population } \\
\text { centre (abandoned } \\
\text { municipality) }\end{array}$ & $\begin{array}{l}\text { Ratio of the } \\
\text { population centre } \\
\text { of initiator to } \\
\text { abandoned* }\end{array}$ \\
\hline Izabelin (R) & 3550 & Stare Babice (R) & 2000 & 1.77 \\
\hline Krościenko Wyżne (R) & 5398 & Korczyna (R) & 6047 & 0.89 \\
\hline Ksawerów (R) & 6550 & Pabianice (R) & 5270 & 1.24 \\
\hline Regnów (R) & 332 & Cielądz (R) & 806 & 0.41 \\
\hline Skarżysko Kościelne (R) & 2339 & Mirzec (R) & 2121 & 1.10 \\
\hline Słopnice (R) & 6189 & Tymbark (R) & 2840 & 2.18 \\
\hline Spytkowice (R) & 4262 & Raba Wyżna (R) & 4243 & 1.00 \\
\hline Trzciana (R) & 1510 & Żegocina (R) & 1685 & 0.90 \\
\hline Jaśliska (R) & 413 & Dukla (UR) & 2212 & 0.19 \\
\hline Kościelisko (R) & 4403 & Gmina Tatrzańska (UR) & 28337 & 0.16 \\
\hline Poronin (R) & 4195 & Gmina Tatrzańska (UR) & 28337 & 0.15 \\
\hline Łączna (R) & 903 & Suchedniów (UR) & 9117 & 0.10 \\
\hline Powidz (R) & 1313 & Witkowo (UR) & 8151 & 0.16 \\
\hline Rytro (R) & 2273 & Piwniczna-Zdrój (UR) & 6088 & 0.37 \\
\hline Stoczek Łukowski (U) & 2806 & Stoczek Łukowski (UR) & 2806 & 1.00 \\
\hline
\end{tabular}

Note: $R$ - rural municipality, UR - urban-rural municipality; * - the closer to 1, the more similar Source: own calculation based on Main Statistical Office data (2020).

central authorities), splits occurred and new municipalities were created.

After 1998 the Central Government introduced more stringent criteria for creating municipalities, taking into account demographic and economic factors. Additionally, the applicable legal provisions on maximum territorial cohesion and the ability to perform public tasks were interpreted more rigorously. Over time, requests to reactivate municipalities have increasingly met with a negative assessment by the Central Government. The Ministry of Interior and Administration claimed that territorial fragmentation is a tendency against Central Government policy. The declared objective of central policy is to maintain large and strong local governments that have greater budgetary capabilities, and greater potential to absorb EU funds and manage public funds more efficiently. As a result, in 1999-2019, only one municipality was created in Poland - Jaśliska, located on the Polish-Slovak border in a mountainous area. The municipality of Jaśliska had been making huge efforts to reactivate local government from 2006 and only succeeded after the third attempt. In accordance with the regulation adopted by the Ministry, the local government unit was created on 1 January 2010. The Ministry of Interior and Administration, examining the municipality's application, treated this case more favourably than the previous ones. The municipality of Jaśliska had only 2,109 inhabitants and its local budget was not very affluent, but it was neither the smallest nor the poorest municipality in Poland. So, no rule was broken. This further emphasizes how the rules established by the law leave plenty of room for the Ministry to interpret them freely. The

${ }^{16}$ Due to data unavailability, analysis is based on data from 2009 positive decision of the Ministry was justified primarily by social and geographical arguments, such as:

$\checkmark \quad$ strong support for the split by the inhabitants of the local community (around $8 \%$ of eligible residents of the Dukla municipality took part in social consultations organized at the beginning of 2009 , of which $98 \%$ voted in favour of creating the new municipality),

$\checkmark$ social, historical and economic ties,

$\checkmark$ homogeneity of the territory in terms of settlement and compactness of the inhabited area,

$\checkmark$ quite a long distance from the seat of the current municipality of Dukla $(18.5 \mathrm{~km})$, resulting in difficult access to local services for the inhabitants of Jaśliska, which was an obstacle - especially during winter - due to difficult terrain.

Finding an influential Central Government politician, who would be a patron of the split, may be an effective strategy of the initiators (Swianiewicz, Gendźwiłł \& Łukomska 2018). The division of the Stoczek Łukowski municipality was supported by influential central level politicians (related to a left-wing party). Also, in the case of the split of the Raba Wyżna municipality, support from important national politicians was identified (this time representatives came from the right-wing to provide political support).

Unsuccessful splits in Polish local governments

In recent years, for various reasons, the desire to become independent and establish a new local government has been reported by at least 10 local communities (Table 4). In particular, 
Table 4. Unsuccessful attempts for municipal divorce

\begin{tabular}{|c|c|c|c|c|}
\hline $\begin{array}{l}\text { Municipality: } \\
\text { initiator (name } \\
\text { and population) }\end{array}$ & $\begin{array}{l}\text { 'Mother' municipality } \\
\text { (name and population } \\
\text { size, excluding initiator) }\end{array}$ & $\begin{array}{l}\text { Local } \\
\text { referendum } \\
\text { (date, result) }\end{array}$ & $\begin{array}{l}\text { Other activities to create new local } \\
\text { government and the dates of the initiatives }\end{array}$ & $\begin{array}{l}\text { Historical past } \\
\text { of being a } \\
\text { separate unit }\end{array}$ \\
\hline $\begin{array}{l}\text { Łagiewniki } \\
\text { c. } 2,000\end{array}$ & $\begin{array}{l}\text { Łódź } \\
\text { c. } 758,250\end{array}$ & No referendum & 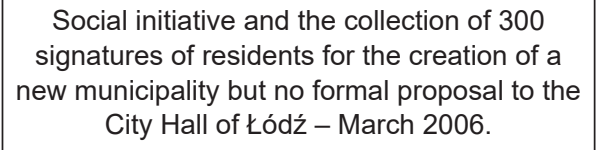 & $\begin{array}{l}\text { Until } 1946, \\
\text { separate } \\
\text { municipality }\end{array}$ \\
\hline $\begin{array}{l}\text { Chełmsko } \\
\text { Śląskie } \\
\text { c. } 3,124\end{array}$ & $\begin{array}{l}\text { Lubawka } \\
\text { c.8,717 and Kamienna } \\
\text { Góra c. } 8,424\end{array}$ & No referendum & $\begin{array}{l}\text { Formal proposal for the creation of a new } \\
\text { municipality submitted to the municipal council } \\
\qquad-2007 .\end{array}$ & $\begin{array}{l}\text { 1945-1972, } \\
\text { separate } \\
\text { municipality }\end{array}$ \\
\hline $\begin{array}{l}\text { Komorów } \\
\text { c.5,670 }\end{array}$ & $\begin{array}{l}\text { Michałowice } \\
\text { c. } 10,760\end{array}$ & No referendum & $\begin{array}{c}\text { Establishment of a social initiative to create } \\
\text { the municipality of Komorów; written support } \\
\text { from over 1,000 inhabitants - March } 2009 . \\
\text { Petition of known central level politicians to } \\
\text { the Ministry of Interior and Administration - } \\
\text { July } 2009 .\end{array}$ & $\begin{array}{l}\text { Until } 1972, \\
\text { separate } \\
\text { municipality }\end{array}$ \\
\hline $\begin{array}{l}\text { Miasto Śląskie } \\
\text { c. } 24,000\end{array}$ & $\begin{array}{l}\text { Mysłowice } \\
\text { c. } 51,300\end{array}$ & No referendum & $\begin{array}{l}\text { Social initiative coming from the inhabitants of } \\
8 \text { southern districts of the city of Mysłowice - } \\
\text { October } 2012 \text {. } \\
\text { Referendum proposal (January 2013): } \\
\text { rejected. }\end{array}$ & \\
\hline $\begin{array}{l}\text { Szczawa } \\
\text { c. } 2,000\end{array}$ & $\begin{array}{l}\text { Kamienica } \\
\text { c. } 5,750\end{array}$ & $\begin{array}{l}22.09 .2013 \\
\text { Invalid: turnout } \\
13.5 \%\end{array}$ & $\begin{array}{l}\text { Approval of the Ministry for the creation of } \\
\text { the new municipality but the new parliament } \\
\text { repealed the regulation prepared by the } \\
\text { previous government - second half of } 2015 \text {. }\end{array}$ & $\begin{array}{l}\text { 1954-1961, } \\
\text { separate } \\
\text { municipality }\end{array}$ \\
\hline $\begin{array}{l}\text { Grabówka } \\
\text { c. } 7,600\end{array}$ & $\begin{array}{l}\text { Supraśl } \\
\text { c.7,500 }\end{array}$ & $\begin{array}{l}24.05 .2015 \\
\text { Turnout } 62 \% \\
\text { (combined with } \\
\text { presidential } \\
\text { election) ( } 45 \% \\
\text { for the division) }\end{array}$ & $\begin{array}{l}\text { Approval of the Ministry for the creation of } \\
\text { the new municipality but the new parliament } \\
\text { repealed the regulation prepared by the } \\
\text { previous government - second half of } 2015 \text {. }\end{array}$ & $\begin{array}{l}\text { 1954-1972, } \\
\text { separate } \\
\text { municipality }\end{array}$ \\
\hline $\begin{array}{l}\text { Jankowice } \\
\text { c. } 4,000\end{array}$ & $\begin{array}{l}\text { Świerklany } \\
\text { c. } 8,000\end{array}$ & $\begin{array}{l}06.01 .2013 \\
\text { Invalid: turnout } \\
27.1 \%\end{array}$ & $\begin{array}{c}\text { In January 2012, the municipal council of } \\
\text { Swierklany received a formal proposal to take } \\
\text { statutory actions regarding the separation of a } \\
\text { new municipality. }\end{array}$ & $\begin{array}{l}\text { 1946-1972, } \\
\text { separate } \\
\text { municipality }\end{array}$ \\
\hline $\begin{array}{l}\text { Majdan Stary } \\
\text { c. } 2,600\end{array}$ & $\begin{array}{l}\text { Księżpol } \\
\text { c. } 4,300\end{array}$ & $\begin{array}{l}\text { 13.01.2013 } \\
\text { Invalid: turnout } \\
28.3 \%\end{array}$ & $\begin{array}{l}\text { In October 2011, a formal proposal submitted } \\
\text { to the municipal council of Księżpol. }\end{array}$ & \\
\hline $\begin{array}{l}\text { Kamyk } \\
\text { c. } 3,700\end{array}$ & $\begin{array}{l}\text { Kłobuck } \\
\text { c. } 17,000\end{array}$ & $\begin{array}{c}\text { 19.01.2014 } \\
\text { Invalid: turnout } \\
15.7 \%\end{array}$ & $\begin{array}{c}\text { On } 5 \text { March } 2013 \text {, a representative of the } \\
\text { referendum initiators submitted an official } \\
\text { request to the mayor of Kłobuck for a } \\
\text { referendum. } \\
\text { The date of the referendum was set for } \\
\text { 14 July 2013; however, the referendum did not } \\
\text { take place due to the lack of the timely opinion } \\
\text { of the regional office. } \\
\text { In December } 2013 \text {, after an appeal to the } \\
\text { Regional Administrative Court, the electoral } \\
\text { commissioner announced a new date for the } \\
\text { referendum. }\end{array}$ & $\begin{array}{l}\text { Until } 1976 \text {, } \\
\text { separate } \\
\text { municipality }\end{array}$ \\
\hline $\begin{array}{l}\text { Huta-Dąbrowa } \\
\text { c. } 1,300\end{array}$ & $\begin{array}{l}\text { Krzywda } \\
\text { c. } 9,400\end{array}$ & No referendum & $\begin{array}{l}\text { Establishing an association for the new } \\
\text { municipality of Huta-Dąbrowa (2012). }\end{array}$ & \\
\hline
\end{tabular}

Source: own desk research 
after the municipality of Jaśliska succeeded in 2010, there was a 'flood' of attempts to secede.

Often, in the case of initiatives aimed at establishing a new municipality, groups of more than 15 people submitted a proposal for a local referendum (in 6 out of 10 identified divorce attempts). Usually, referendums were held but, in most cases, they were invalid due to a turnout that was too low. In some municipalities, other initiatives were also undertaken, such as seeking support among well-known politicians and even celebrities (actors, musicians) as in the case of Komorów (a wealthy community located near Warsaw with the historical past of being a 'Garden City').

What were the reasons and arguments most often raised by the initiators of the division? There was often a reference to history and to having been an independent administrative unit in the past. Sometimes the initiators referred to cases of successful divorces, especially among neighbouring municipalities or in neighbouring counties. For example, the inhabitants of Kamyk were envious of the success of the Boronów municipality located in the neighbouring county, which separated from the Herby municipality in 1993; restitution initiators of the Majdan Stary municipality referred to the examples of Aleksandrów (separated from the Józefów municipality in 1992) and Biszcza (created in 1982), municipalities that separated from the same Biłgorajski county. They based their thinking on the principle: 'others have succeeded in regaining local government and they are satisfied so let's give it a try'. There were also frequent arguments related to being marginalized in the context of investments or inadequate care of monuments, and historical heritage.

An unusual situation occurred in the case of attempts to split the Kamienica and Supraśl municipalities. Following the submission of proposals by municipalities and the conducting of local referendums, the Central Government prepared a regulation to create the new municipalities: Grabówka and Szczawa. On 28 July 2015, the Central Government issued a regulation establishing the Szczawa and Grabówka municipalities from 1 January 2016. But in October 2015, as a result of parliamentary elections, there was a change of Central Government. The new government decided not to divide local governments. On 28 December 2015 (only 3 days before the new law was to come into force), a regulation repealing the earlier law adopted was issued. To justify not establishing the municipalities of Grabówka and Szczawa, the Central Government referred to the negative results of local referendums that were conducted in the abovementioned municipalities as part of public consultations.

\section{Conclusions}

In conclusion, it should be noted that there was usually no single factor to sufficiently explain the reasons for the splits of the Polish municipalities being researched. In most cases we were dealing with a favourable constellation of several factors. It is also difficult to indicate the most powerful arguments behind the divisions of municipalities.
Economic arguments dominate the discussion on the need for territorial reforms, both those aimed at amalgamation and those dealing with territorial fragmentation (Gendźwiłt, Kurniewicz \& Swianiewicz 2020). Despite the fact that the expert survey of countries with cases of municipal splits (presented by Swianiewicz 2021) suggests that the reasons related to economic factors seem to be the most powerful argument in the discourse of recent municipal secessions, the results of this article indicate that cultural factors appear to be at least as important as economic ones in Poland. Thus, as expected after our literature review, 'economic' reasons for the splitting of municipalities turn out to be not as prevalent as anticipated. Research shows that economic arguments speak more for the concentration of municipalities than for territorial fragmentation (economies of scale are important above all). We can find examples of studies that indicate the negative economic effects of municipal divisions, such as an increase in capital expenditure (Lima \& Neto 2018), the free-riding effect (Hinnerich 2009), a hindrance for local development, and local selfishness (Firman 2013). It is possible that, for this reason, in the case of municipal splits in Poland, the economic arguments were not addressed, but other reasons were brought to the fore by the supporters of the divisions.

Cultural explanations related to the 'restitution of the former splendour' turned out to be of considerable importance in the case of municipal divisions. The research conducted has shown that an important argument in the debate on the creation of a new municipality (both in the case of successful and unsuccessful splits) was the memory of the inhabitants of the period in which they operated as a separate municipality.

In the case of rural municipalities, the existence of a second population centre in the municipality of almost equal importance, was an important factor that contributed to the municipal splits. Thus, at least in the case of rural municipalities, the geographical differences (the second population centre) that led to splits turned out to be more important in Poland than the economic explanations.

The different determinants of municipality divorces are closely related but, taking into account the results of the analysis, it can be claimed that, in Polish circumstances, environmental factors (in particular, in relation to the history and memory of inhabitants of the period in which they operated as a separate municipality) were more significant than political ones.

\section{Acknowledgements}

The paper is based on results of the "Territorial reforms in Europe - comparative perspective" research project. The project has been funded by Narodowe Centrum Nauki (National Science Centre) in Poland, grant number 2017/26/M/HS5/00152.

\section{ORCID}

Julita Łukomska (D) http://orcid.org/0000-0003-3796-7314

\section{References}

Alesina, A \& Spolaore, E 2003, The size of Nations, MIT Press. Baldersheim, H \& Rose, L 2010, Territorial choice: The politics of boundaries and borders, Palgrave-Macmillan, London.

Brink, A 2004, 'The break-up of municipalities: Voting behavior in local referenda', Economics of Governance, vol. 5, no.2, pp. 119-135.

Chojnicki, Z \& Czyż, T 2000, 'Nowa organizacja terytorialna Polski i układ regionalny' ['New Polish territorial organization and regional system'], Czasopismo Geograficzne, vol. LXXI, no. 3-4, pp. 261-277.

Drew, J \& Dollery, B 2014, 'Separation anxiety: an empirical evaluation of the Australian Sunshine Coast Regional Council de-amalgamation', Public Money \& Management, vol. 34, no. 3, pp. 213-220.

Erlingsson, GO 2005, 'Modelling secessions from municipalities', Scandinavian Political Studies, vol. 28, no. 2, pp. 141-159. 
Firman, T 2013, 'Territorial splits (Pemekaran Daerah) in decentralising Indonesia, 2000-2012: Local development drivers or hindrance?', Space and Polity, vol. 17(2), pp. 180-196.

Fox, W \& Gurley, T 2006, 'Will consolidation improve sub-national governments?', Policy Research Working Paper, vol. 3913, World Bank, Washington.

Gendźwiłł, A, Kurniewicz, A \& Swianiewicz, P 2020, 'The impact of municipal territorial reforms on the economic performance of local governments. A systematic review of quasi-experimental studies', Space and Polity, DOI: $10.1080 / 13562576.2020 .1747420$

Hinnerich, BT 2009, 'Do merging local governments free ride on their counterparts when facing boundary reform?', Journal of Public Economics, vol. 93(5-6), pp. 721-728.

Hogen-Esch, T 2001, 'Urban secession and the politics of growth: The case of Los Angeles', Urban Affairs Review, vol. 36, pp. 783-810.

Illner, M 2010, 'Top-down or bottom up? Coping with territorial fragmentation in the Czech Republic' in Territorial choice: The politics of boundaries and borders, eds. $\mathrm{H}$ Baldersheim \& L Rose, Palgrave-Macmillan, London, pp. 214-233.

Izdebski, H 2009, Samorząd terytorialny. Podstawy ustroju i działalności [Local government. Foundations of system and activities], LexisNexis, Warszawa.

Jałowiecki, B (ed) 1995, Funkcjonowanie miastigmin zespolonych [Operation of a merged cities and municipalities], report prepared at the request of Prime Minister's Office.

Jarczewski, W 2002, Odzyskana niezależność. Przyczyny $i$ skutki powstania nowych gmin na obrzeżach GOP w latach 90. [Regained independence. Causes and effects of the creation of new municipalities on the outskirts of Upper Silesian Industrial District in the 1990s], Wydawnictwo Dante, Kraków.

Kaczmarek, T 2005, Struktury terytorialno-administracyjne $i$ ich reformy w krajach europejskich [Territorial administrative structures and their reforms in European countries], Wydawnictwo Naukowe UAM, Poznań.

Kaczmarek, T 2016, 'Gminny podział administracyjny w świetle 25 lat funkcjonowania samorządu terytorialnego w Polsce' [The municipal administrative division in the light of 25 years of local government in Poland], Przegląd Politologiczny, vol. 1, no.21, pp. 63-80.

Kiełczewska-Zaleska, M 1974, 'Dotychczasowy rozwój lokalnej sieci osadniczej a reforma administracyjna wsi z 1973. Na przykładzie powiatów gorlickiego i żuromińskiego' ['The current development of the local settlement network and the local administrative reform from 1973. On the example of the Gorlice and Żuromin counties'], Przegląd Geograficzny, vol. XLVI, no. 2, pp. 205-229.

Ladd, H 1994, 'Fiscal impacts of local population growth: A conceptual and empirical analysis', Regional Science and Urban Economics, vol. 24(1), pp. 661-686.

Lima, RCA \& Neto, RMS 2018, 'Secession of municipalities and economies of scale: Evidence from Brazil', Journal of Regional Science, vol. 58(1), pp. 159-180.

Main Statistical Office 2020. Available from: https://stat.gov.pl/ and https://eteryt.stat.gov.pl/eteryt/raporty/WebRaportZestawienie. aspx. [20 August 2020].

Ministry of Finance 2020. Available from: https://www.gov.pl/ web/finanse/budzety-jst and https://mf-arch2.mf.gov.pl/web/ $\mathrm{bip} / \mathrm{ministerstwo-finansow/dzialalnosc/finanse-publiczne.}$ [20 August 2020].
Ministry of Interior and Administration 2020. Available from: https://www.gov.pl/web/mswia and https://archiwumbip. mswia.gov.pl/. [20 August 2020].

Miszczuk, A 2003, Regionalizacja administracyjna III Rzeczpospolitej. Koncepcje teoretyczne a rzeczywistość [Administrative regionalization of the Republic of Poland. Theoretical concepts and reality], Wydawnictwo Uniwersytetu Marii Curie-Skłodowskiej, Lublin.

Nelson, M 1992, 'Municipal amalgamation and the growth of the local public sector in Sweden', Journal of Regional Science, vol. 32(1), pp. 39-53.

Ocena sytuacji samorządów lokalnych [Assessment of the local government situation] 2013, Ministerstwo Administracji i Cyfryzacji, Warszawa.

Statistic Poland 2020, Local Data Bank. Available from: <https:// bdl.stat.gov.pl/BDL/dane/podgrup/temat>. [20 August 2020].

Swianiewicz, P 2014, Ocena podziału terytorialnego państwa z uwzględnieniem efektywności funkcjonowania urzędów organów jednostek samorządu terytorialnego -wnioski $i$ rekomendacje [Assessment of the territorial division of the state, including the effectiveness of the offices of local government units - conclusions and recommendations], report prepared at the request of Ministry of Digitization and Administration, Warsaw.

Swianiewicz, P 2018, 'If territorial fragmentation is a problem, is amalgamation a solution? - ten years later', Local Government Studies, vol. 44, no. 1, pp. 1-10.

Swianiewicz, P 2021, 'From post-communist democratic laissez-faire to prevention of territorial fragmentation: tightening the rules of municipal splits in Central and Eastern Europe after 1990', Miscellanea Geographica - Regional Studies on Development, vol. 25, no. 1, pp. 5-17.

Swianiewicz, P \& Łukomska, J 2019, 'Is small beautiful? The quasi-experimental analysis of the impact of territorial fragmentation on costs in Polish local governments', Urban Affairs Review, vol. 55, no. 3, pp. 832-855.

Swianiewicz, P, Gendźwiłł, A \& Łukomska, J 2018, 'Inicjatorzy i opuszczeni: demokracja lokalna po gminnych rozwodach' ['The initiators and the abandoned: local democracy after municipal 'divorces"], Prace Geograficzne, no. 154, pp. 7-33.

Swianiewicz, P, Gendźwiłł, A \& Zardi, A 2017, Territorial reforms in Europe: Does size matters. Territorial amalgamation Toolkit, Centre of Expertise for Local Government Reform. Council of Europe, Strasbourg.

Swianiewicz, P, Gendźwiłł, A, Łukomska, J \& Kurniewicz, A 2016, Rozmiar gmin i powiatów a sprawność ich funkcjonowania. Wielkoludy i liliputy [The size of municipalities and counties and the efficiency of their functioning. Giants and lilliputs], Wydawmictwo Naukowe Scholar, Warszawa.

Tanguay, GA \& Wihry, DF 2008, 'Voters' preferences regarding municipal consolidation: evidence from the Quebec demerger referenda', Journal of Urban Affairs, vol. 30, no. 3, pp. 325-345.

Wollmann, H 2010, 'Territorial consolidation reforms in German East Landers' in Territorial consolidation reforms in Europe, ed. P Swianiewicz, LGI-Open Society Institute, Budapest. 